\title{
A study on the distribution of disabilities among the population residing in the endosulfan exposed area in Dakshina Kannada district of Karnataka
}

\author{
Sanjeev Badiger ${ }^{1}$, Ankeeta Menona Jacob ${ }^{1 *}$, Arunkumar Sagar Bangaraiah ${ }^{2}$, \\ Satheesh Kumar Bhandary ${ }^{3}$, Smitha Hegde ${ }^{4}$, Pavan Kumar ${ }^{1}$
}

\begin{abstract}
${ }^{1}$ Department of Community Medicine, KS Hegde Medical Academy, Mangalore, ${ }^{2}$ District Vector Borne Disease Officer and Nodal officer for Endosulfan for Dakshina Kannada District, Dakshina Kannada district, ${ }^{3}$ Nitte (Deemed to be University) Mangalore, Dakshina Kannada District, ${ }^{4}$ Nitte University Centre for Science Education and Research (NUCSER), Paneer, Dakshina Kannada District, Karnataka, India
\end{abstract}

Received: 18 June 2019

Revised: 25 July 2019

Accepted: 30 July 2019

*Correspondence:

Dr. Ankeeta Menona Jacob,

E-mail: neelankeet@gmail.com

Copyright: (C) the author(s), publisher and licensee Medip Academy. This is an open-access article distributed under the terms of the Creative Commons Attribution Non-Commercial License, which permits unrestricted non-commercial use, distribution, and reproduction in any medium, provided the original work is properly cited.

\section{ABSTRACT}

Background: Endosulphan was extensively sprayed in the cashew plantations in over 90 villages in Dakshina Kannada district for almost two decades before a ban was imposed. Areas where Endosulfan spraying was carried out, disability screening camps were conducted. The study aimed at describing the distribution of attendees of the disability screening camps among the population residing in the Endosulfan exposed area of Dakshina Kannada district of Karnataka, India.

Methods: A cross sectional descriptive was undertaken with the permission of district health authorities by specialists in the villages of five taluks, on the patients attending the disability screening camps conducted in the year 2014-15. The patients were consecutively listed and classified based on the Persons with Disabilities Act, 1995 and analysed using SPSS version 20.0.

Results: Of the 4214 patients who attended the screening camps for disability held in the taluks mentioned above, $2190(52.0 \%)$ were males. The most common affected age groups were between 5-19 years of $1606(38.1 \%)$. The most common disability was intellectual disability (including cerebral palsy) in $2474(58.7 \%)$ followed by physical disability seen in $384(15.5 \%)$. Infertility was seen among 297 (7.09\%) of the attendees of the screening camps. The total number of cancers patients attending the screening camps was $71(1.6 \%)$, and $21(0.5 \%)$ were cancers related to the reproductive tract, and $6(0.1 \%)$ had breast cancer.

Conclusions: The most common age groups reporting with disabilities to the screening camps conducted by the district health authorities in Endosulfan sprayed villages of Dakshina Kannada district belonged to 5-19 years, and the most common disability was intellectual disability.

Keywords: Endosulfan, Disabled persons, Teratogenicity, Infertility, Intellectual disability

\section{INTRODUCTION}

Endosulfan also called as benzoin, endocel, hildan, thiodan and thionex is an off-patent organochlorine pesticide with known effects of DNA damage, a mutation in somatic, and sex chromosomes. ${ }^{1}$ Endosulfan acts like an endocrine disruptor by the enhancement of the estrogenic effect on reproductive and other somatic cell lines in animals and humans. ${ }^{2}$ This action of Endosulfan has found to be toxic to whiteflies, aphids, leafhoppers, Colorado potato beetles and cabbage worms and moderately toxic to honey bees. ${ }^{3-5}$ Endosulfan can be 
considered as one of the most toxic pesticides in the market today, with many countries reporting accidental and intentional harm caused due to the use of this compound. ${ }^{6}$ The national meeting on the health hazards of Endosulfan and need for ban held in 2011 showed that in Kasargod district of Kerala about 9000 victims of Endosulfan had been identified of which 4800 are bedridden and more than a thousand have lost their lives. ${ }^{7}$ An ever-growing demand of the survivors against the use of Endosulfan for more than ten years has resulted in two states, namely Kerala and Karnataka Governments, to ban the use of Endosulfan. ${ }^{7}$ The district of Dakshina Kannada also has many cashew plantations where the use of Endosulfan was observed in the form of spraying over the cashew trees in the estate under the cashew development corporation. Over 90 villages in the five taluks of Dakshina Kannada district covering more than a thousand hectares of cashew plantation for about two decades have been using this pesticide. ${ }^{8}$ A study conducted by Dayakar et al in 2002 in one of the Endosulfan exposed villages in Belthangady Taluk of Dakshina Kannada district, Karnataka, India reported that there was an increase in the number of cancers, skin problems, infertility and children born with mental and physical defects. ${ }^{8}$ Based on the recommendations of National Human Rights Commission (NHRC), the National Institute of Occupational Health (NIOH) conducted a thorough epidemiological study which found that there was a significantly higher prevalence of neurobehavioural disorders, a congenital malformation in females and abnormalities related to the male reproductive system. ${ }^{9}$ However, quantitatively no study has been undertaken to determine the prevalence of the disabilities among these populations at the five taluks of the Dakshina Kannada district of Karnataka. Given this, the study aimed to describe the distribution of disabilities among the population residing in the Endosulfan exposed area in Dakshina Kannada district of Karnataka

\section{METHODS}

Though a previous study mentioned more than 90 villages with purported Endosulfan spraying in Dakshina Kannada district, only 69 villages reported the use of Endosulfan. ${ }^{8}$ The total area covered was about 3500 hectares. The disability screening camps were conducted by District Health Office of Dakshina Kannada district, Karnataka to identify the disability among the population in Dakshina Kannada district where Endosulfan spraying was carried out. The screening camps were held in five taluks of Dakshina Kannada taluks, namely, Bantwala, Belthangady, Mangalore, Puttur, and Sullia as shown in Figure 1. Specialist doctors in paediatrics, general medicine, ophthalmology, otorhinolaryngology and psychiatry used the persons with disabilities (equal opportunities, protection of rights and full participation) act of 1995, to diagnose the types of disabilities among the attendees of the disability screening camps. The screening camps were conducted for a year between 2014 to 2015. Secondary data analysis after appropriate permissions for data was obtained from district authorities. Additionally, ethical clearance from the college authorities also was obtained. The secondary data thus obtained was evaluated for any missing data and appropriately excluded from the analysis. The data attending the disability screening camps of the age and sex of the patients, type of disability and the percentage of the disability Persons with Disabilities (Equal Opportunities, Protection of Rights and Full Participation Act, 1995 of the attendees to the camps using a prestructured proforma. The data were entered into MS Excel and analysed using SPSS (Statistical Package for Social Sciences) version 20.0. Descriptive statistics of percentages and proportions were used to describe the data.

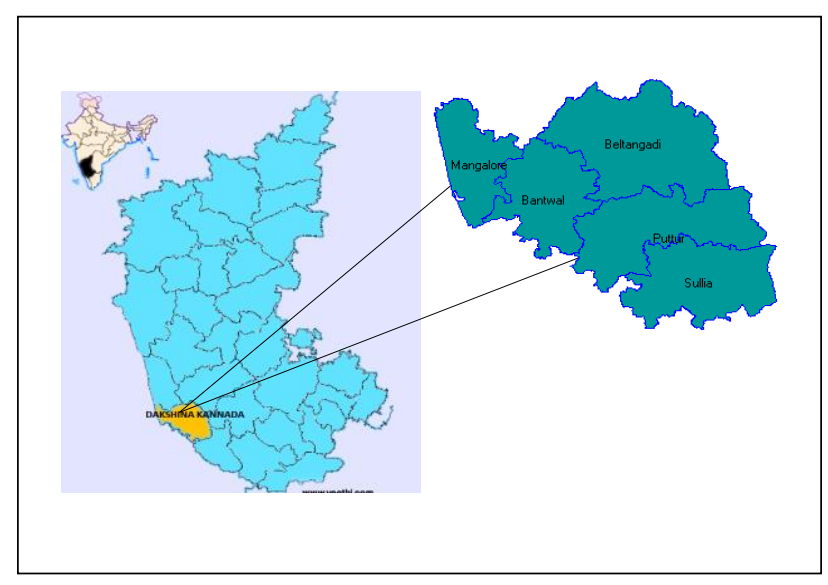

Figure 1: Geographic location of the five taluks of Dakshina Kannada affected by extensive use of Endosulfan.

\section{RESULTS}

The taluks in which the disability screening camps were conducted is shown in Figure 2. The distribution of the attendees of the disability screening camps in the various taluks is shown in Table 1. The maximum number of patients were from Puttur taluk 1661 (39.4\%), and the least number of patients were from Sullia Taluk 312 (7.4\%). About $2190(52.0 \%)$ of the 4214 patients examined were males.

Table 1: Taluk wise distribution of the attendees of the disability screening camps in Dakshina Kannada district of Karnataka.

\begin{tabular}{|lll|}
\hline Taluk & Frequency & $\%$ \\
\hline Bantwal & 455 & 10.8 \\
\hline Belthangady & 1433 & 34.0 \\
\hline Mangalore & 353 & 8.4 \\
\hline Puttur & 1661 & 39.4 \\
\hline Sullia & 312 & 7.4 \\
\hline Total & 4214 & 100.0 \\
\hline
\end{tabular}

The age group-wise distribution of the attendees of the disability screening camps in the five taluks of Dakshina 
Kannada district, Karnataka is shown in Table 2. Specialists measured the extent of disability based on Persons with Disabilities (Equal Opportunities, Protection of Rights, and Full Participation) Act 1995. The different types of disabilities seen in attending the screening camps held in the five taluks in Dakshina Kannada are shown in Figure 1. The most common disability was the intellectual disability (including cerebral palsy) seen in $2474(58.7 \%)$, which was followed by physical disability seen in $384(15.5 \%)$. The total number of cancers patients attending the screening camps was $1.6 \%$ and $0.5 \%$ were cancers related to the reproductive tract and $0.1 \%$ had breast cancer.

Table 2: Age-wise distribution of the attendees of the disability screening camps in the five taluks of Dakshina Kannada district of Karnataka.

\begin{tabular}{|lll|}
\hline Age group (in years) & Frequency & $\%$ \\
\hline Less than five & 233 & 5.5 \\
\hline $\mathbf{6 - 1 5}$ & 1077 & 25.6 \\
\hline $\mathbf{1 6 - 2 5}$ & 1037 & 24.6 \\
\hline $\mathbf{2 6 - 3 5}$ & 908 & 21.5 \\
\hline $\mathbf{3 6 - 4 5}$ & 468 & 11.1 \\
\hline More than 46 & 482 & 11.4 \\
\hline Age not specified & 9 & 0.3 \\
\hline Total & 4214 & 100.0 \\
\hline
\end{tabular}

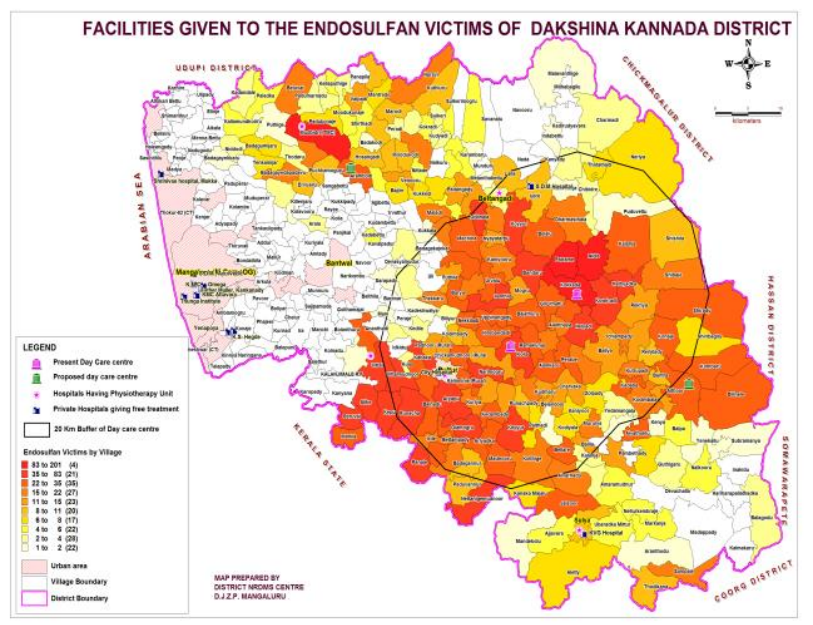

Figure 2: The taluks where the disability screening camps were conducted in Dakshina Kannada District, Karnataka.

Source: Maps created based on data obtained on facilities provided to Endosulfan victims by, Dakshina Kannada district Health and Family welfare department, Dakshina Kannada District, Karnataka.

Table 3 shows the percentage of disability measured as per the Persons with Disabilities (Equal Opportunities, Protection of Rights and Full Participation) Act of 1995 among the attendees of disability screening camps in the five taluks of Dakshina Kannada district, Karnataka. Most of the individuals who had a disability had 40-75\% of disability seen in $2152(51.1 \%)$ attendees of the disability screening camps.

Table 3: The percentage of disability among the attendees of the disability screening camps in

Dakshina Kannada district, Karnataka.

\begin{tabular}{|lll|}
\hline Percentage of disability & Frequency & $\%$ \\
\hline No disability & 547 & 13.0 \\
\hline $\mathbf{1 - 4 0}$ & 338 & 8.0 \\
\hline $\mathbf{4 1 - 7 5}$ & 2152 & 51.1 \\
\hline More than 75 & 1177 & 27.9 \\
\hline Total & 4214 & 100.0 \\
\hline
\end{tabular}

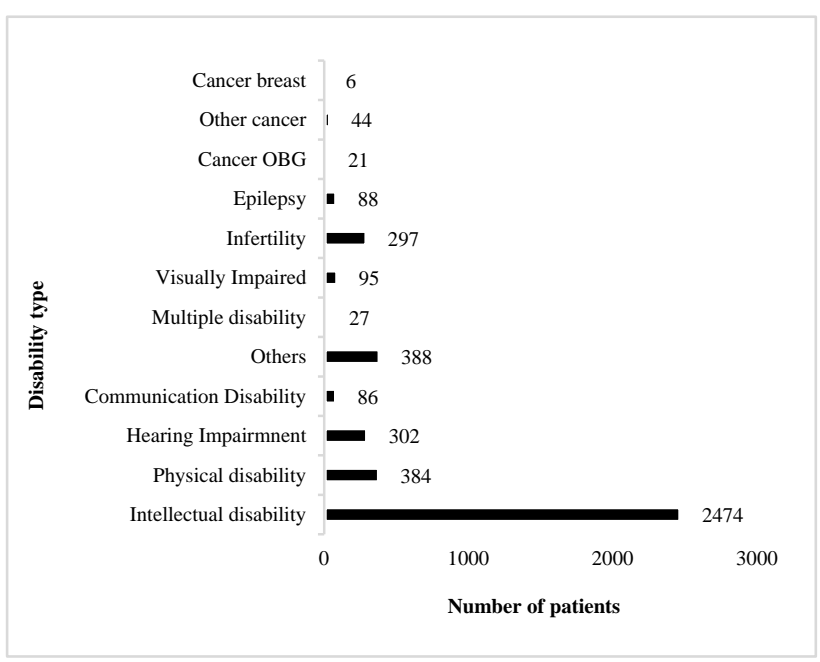

Figure 3: Disability wise distribution of the patients attending the disability screening camps in Dakshina Kannada districts.

\section{DISCUSSION}

The present study has attempted to highlight the disabilities among the individuals attending the disability screening camps held in the five taluks of the Dakshina Kannada district, Karnataka, where there was Endosulfan spraying conducted. The National Institute of Occupational Health in Ahmedabad in its final report showed that higher prevalence of learning disability and neurobehavioral disorders were seen in Kasaragod district of Kerala however our study indicated that the most common disability was Intellectual disability (including cerebral palsy). ${ }^{9}$ In Kasaragod, Kerala state the medical camps were conducted and found that workers in areas where endosulphan was sprayed, the most common disabilities were found to be mental retardation and physical disability which was similar to the present study. ${ }^{10}$

The study also highlighted that the incidence of mental retardation in areas with aerial spraying was almost eleven times higher in sprayed areas (971 cases) compared to that of non-sprayed areas (83 cases). 
A study conducted by Embrandiri et al which showed up to $74.5 \%$ males and $74.1 \%$ of the 1000 respondents had mental retardation and the highest rates of mental retardation was seen among individuals aged zero to fourteen years of age which were similar to our study where the individuals with disabilities were from the age groups of 6 to 15 years of age $1077(25.6 \%) .{ }^{11}$ The survey conducted by Embrandiri et al in the Kasargod District of Kerala showed that the most common health effects in the areas where Endosulfan was used in the district. ${ }^{11}$ This study showed that $46 \%$ of boys and $42.5 \%$ of girls less than 14 years had congenital anomalies; however, our review was not able to capture these congenital anomalies. The survey also showed that $74.5 \%$ of the males and $74.1 \%$ of the females under age 30 had mental retardation which had comparable rates of disability to the present study. ${ }^{11}$

\section{CONCLUSION}

The most common age groups reporting with disabilities to the screening camps conducted by the district health authorities in Endosulfan sprayed villages of Dakshina Kannada district belonged to 5-19 years and the most common disability was intellectual disability (including cerebral palsy). Most of the disabilities were moderate to severe $(40-75 \%)$ disability.

This study highlights the disabilities in the areas where Endosulfan spraying was done. Further, it is recommended that studies exploring the reasons for the disabilities especially in age groups of 5-19 years should be undertaken in these areas. Additional environmental studies could also be undertaken to determine the deleterious effects of Endosulfan in the environment even after several years of the ban.

\section{ACKNOWLEDGEMENTS}

The authors acknowledge the support of the District Health Office of Dakshina Kannada district, Karnataka and the specialists who have supported the disability screening camps in the five taluks of Dakshina Kannada district, Karnataka.

\section{Funding: No funding sources}

Conflict of interest: None declared

Ethical approval: The study was approved by the Institutional Ethics Committee

\section{REFERENCES}

1. 5-Norbornene-2, 3-dimethanol, 1, 4, 5, 6, 7, 7hexachloro-cyclic sulfite. Centers for Disease Control and Prevention, 2018. Available at
https://www.cdc.gov/niosh-rtecs/RB8D8678.html. Accessed 17 June 2019.

2. Andersen HR, Vinggaard AM, Rasmussen TH, Gjermandsen IM, Bonefeld-Jorgensen CE. Effects of currently used pesticides in assays for estrogenicity, androgenicity and aromatase activity in vitro. Toxicol Appl Pharmacol. 20025;179(1):112.

3. Cooper J, Dobson H. The benefits of pesticides to mankind and the environment. Crop Prot. 2007;26(9):1337-48.

4. Kannan K, Holcombe RF, Jain SK, AlvarezHernandez X, Chervenak R, Wolf RE, et al. Evidence for the induction of apoptosis by Endosulfan in a human T-cell leukemic line. Mol Cell Biochem. 2000;205(1-2):53-66.

5. Mehta S, Bhavsar B, Nagane R. Mutagenicity of Endosulfan by Salmonella Typhimurium reverse mutation assay. J Environ Res Dev. 2012;7(1a):40510.

6. Pesticide Residues in Food Evaluations 2006. 1st ed. Rome, Italy: World Health Organization; 2009: 595.

7. Buckwald SS, Buckwald J. Speaking truth saves lives in the Philippines and India. PAN North America Magazine. 2006;304:24-7.

8. Dayakar MM, Shivprasad D, Dayakar A, Deepthi CA. Assessment of oral health status among Endosulfan victims in Endosulfan relief and remediation cell- a cross-sectional survey. J Indian Soc Periodontol. 2015;19(6):709.

9. Final Report of the Investigation of Unusual Illnesses allegedly produced by Endosulfan exposure in Padre Village of Kasargod District (N.Kerala). Ahmedabad: National Institute of Occupational Health; 2002: 98. Available at http://www.indiaenvironmentportal.org.in/files/NIO H-FinalReport.pdf. Accessed 11 May 2019.

10. Health Hazards of Aerial Spraying of endosulphan in Kasargod District, Kerala. Kerala: Government of Kerala; 2003. Available at http://www.India environmentportal.org.in/files/KeralaGovt_FinalRep ort.pdf. Accessed 11 May 2019.

11. Embrandiri A, Singh RP, Ibrahim HM, Khan AB. An epidemiological study on the health effects of Endosulfan spraying on cashew plantations in Kasaragod District, Kerala, India. Asian J Epidemiol. 2012;5(1):22-31.

Cite this article as: Badiger S, Jacob AM,

Bangaraiah AS, Bhandary SK, Hegde S, Kumar P. A study on the distribution of disabilities among the population residing in the endosulfan exposed area in Dakshina Kannada district of Karnataka. Int J Community Med Public Health 2019;6:3948-51. 